\title{
MS14-P31 | CRYSTAL CHEMISTRY OF STRUVITE AND ITS DERIVATIVES
}

Kiriukhina, Galina (Lomonosov Moscow State University, Moscow, RUS); Yakubovich, Olga (Lomonosov Moscow State University, Moscow, RUS)

Single crystals of $\mathrm{CsMn}\left(\mathrm{H}_{2} \mathrm{O}\right)_{6}\left(\mathrm{PO}_{4}\right)$ were synthesized under medium-temperature hydrothermal conditions. The new compound was established to be the first $\mathrm{Mn}$ member and the second hexagonal modification in the struvite morphotropic series of phosphates and arsenates, with hydrogen bonding between the main structural units.

Crystal chemical analysis of the new phosphate in comparison with other members of the family revealed general features for the struvite morphotropic series, $A M\left(\mathrm{H}_{2} \mathrm{O}\right)_{6}\left(X_{4}\right)$, where $A=\mathrm{K}, \mathrm{NH}_{4}, \mathrm{Rb}, \mathrm{H}_{2} \mathrm{O}, \mathrm{Cs}$, and $\mathrm{TI}, M=\mathrm{Mn}, \mathrm{Fe}$, $\mathrm{Co}, \mathrm{Ni}$, and $\mathrm{Mg}$, and $\mathrm{X}=\mathrm{P}, \mathrm{As}$. It has been shown that a regular increase of the unit-cell parameters of the arsenate members correlates to the larger size of $\mathrm{AsO}_{4}$ tetrahedra compared to the size of $\mathrm{PO}_{4}$ tetrahedra. The morphotropic transformation of orthorhombic structures for hexagonal and cubic ones is discussed to be caused by the size of the atoms in the $A$ position. The tendency for growth of the $c$ and reduction of the $a$ unit-cell parameter of orthorhombic $\mathrm{Mg}$ members of the struvite family was shown to correlate with the ionic radius of the $A$ atom $\left(A=\mathrm{K}, \mathrm{NH}_{4}, \mathrm{Tl}\right.$ and $\left.\mathrm{Rb}\right)$.

The symmetry change from cubic in $\operatorname{CsMg}\left(\mathrm{H}_{2} \mathrm{O}\right)_{6}\left(\mathrm{PO}_{4}\right)$ to tetragonal in $\mathrm{Na}\left(\mathrm{H}_{2} \mathrm{O}\right) \mathrm{Mg}\left(\mathrm{H}_{2} \mathrm{O}\right)_{6}\left(\mathrm{PO}_{4}\right)$ was demonstrated to be caused by the ordering of $\mathrm{Na}$ atoms and water molecules in their surroundings. Crystal structure transformation from struvite- $\mathrm{K}, \mathrm{KMg}\left(\mathrm{H}_{2} \mathrm{O}\right)_{6}\left(\mathrm{PO}_{4}\right)$, to hazenite, $\mathrm{KNa}\left(\mathrm{H}_{2} \mathrm{O}\right)_{2} \mathrm{Mg}_{2}\left(\mathrm{H}_{2} \mathrm{O}\right)_{12}\left(\mathrm{PO}_{4}\right)_{2}$, was discussed in order to explain the fourfold increase of the baxis in the case of hazenite. 